\title{
The use of cellular communication masts for wind share research
}

\author{
Valerijs Bezrukovs ${ }^{1}$, \\ Vladislavs Bezrukovs², \\ Sabine Upnere ${ }^{2}$, \\ Linda Gulbe ${ }^{2}$, \\ Deniss Bezrukovs ${ }^{3}$ \\ ${ }^{1}$ Institute of Physical Energetics, \\ Krivu St. 11, \\ 1006 Riga, Latvia \\ ${ }^{2}$ Ventspils University College, \\ Inzenieru St. 101, \\ 3601 Ventspils, Latvia \\ Email:vladislavsb@venta.lv \\ ${ }^{3}$ Riga Technical University, \\ Azenes St. 12/1, \\ 1048 Riga, Latvia
}

Prior to the start of any Wind Power Park construction project, it is necessary to carefully assess available wind potential in the selected area. The cost of such investigative studies is considerable - even with a relatively small $70 \mathrm{~m}$ tall mast it reaches several tens of thousands of Euros. In order to reduce costs related to wind speed measurements it is suggested to use the existing cellular communication masts that are widely spread in Europe. The study presents a methodological approach and the results of wind speed and wind shear measurements performed with the use of lattice cellular communication masts at the height of up to $100 \mathrm{~m}$. A CFD model of airflow around a cellular communication mast structure was created in order to explore the impact of mast structure on the quality of wind speed measurements. The paper presents the results of the CFD modelling in the form of contour maps depicting the severity of airflow disturbances around the mast. The study is based on experimental measurements conducted in 2018 in three coastal sites of Latvia. At each site wind speed and direction were measured at several heights along with air temperature, humidity and air pressure. The experimentally obtained data in combination with the analysis of modelled CFD results shows the possibility of using cellular communication masts for accurate measurements of wind speed. Overall, the study shows that the proposed approach to wind speed measurements can result in high quality data and reduced overall expenses.

Keywords: wind speed measurements, CFD modelling, lattice mast, wind shear

\section{INTRODUCTION}

The starting point of any decision regarding the construction of a wind power generator is the evaluation of wind energy potential at the selected construction site. Wind measurement complexes are the main tools that are used in order to evaluate the potential performance of a future Wind Power Park (WPP). A typical measurement toolkit is composed of a cup sensor and a recording unit, which are installed on a mast at the potential WPP construction site. In order to exclude the impact of the surface on measurements, the height of the mast used for the assessment of wind energy potential should exceed $30 \mathrm{~m} \mathrm{[1]}$.

In order to save time and financial resources involved in the deployment of new wind 
speed measurement complexes it is possible to use the existing network of cellular communication masts. This would allow minimizing the installation and assembly costs of the measurement equipment. At the same time, measurement results should be in compliance with the requirements set by the international standard IEC 61400-12-1 [2]. The standard has been designed to provide uniform methodology to ensure consistency, accuracy and reproducibility of measurements and analysis of wind turbine power performance.

Therefore, it is important to ensure that mast structure does not introduce distortions in the airflow that would cause $>1 \%$ error in the measurements of wind speed. In practice, the task of wind shear analysis can be made cheaper and much simpler if cellular communication masts are used for installing measuring sensors [3]. In this case, it is of interest to investigate the influence of the design elements of these masts on the distribution of air flow and to evaluate the possibility of their use for obtaining reliable wind speed data $[4,5]$.

The IEC standard provides recommendations for calculating the distance from the mast centre at which measurement sensors should be placed [2]. However, study results reported in $[6,7]$ suggest that the boom length calculated in compliance with recommendations of the standard is overestimated. This causes problems with the reliability of the boom mount rigidity during the installation of sensors on the mast $[8,9]$.

This study investigates how wind flow distribution around a communication mast depends on its sizes and design, taking into account communication cables placed inside the mast structure. The extent of the influence exerted by the structural elements of cellular communication masts on the turbulent air flow is analysed using Computational Fluid Dynamics (CFD) modelling of wind flow distribution [10].

The estimation of the degree of influence of the cellular communication mast structure on the results of wind speed measurement was carried out by experimental studies using three lattice masts on which measurement sensors were placed. On each mast 9 measurement sensors at four different height levels were installed. Two anemometers were installed at each of the three levels and at one level three sensors were installed displaced by $120^{\circ}$ from each other. The temperature and direction of the wind were measured at two different levels.

The rest of the paper is structured as follows: Section 2 introduces CFD modelling results of wind flow interaction with a triangular lattice communication mast. Section 3 provides the methodology of the experimental studies of wind speed measurements around a cellular communication mast. Section 4 provides the assessment of the effect of the mast's design on the results of wind speed measurements at the altitude of 10, 40, 64 and $84 \mathrm{~m}$, while Section 5 concludes.

\section{THE MODELLING OF WIND FLOW INTERACTION WITH A TRIANGULAR LATTICE MAST}

In order to estimate the extent to which the structure of a lattice cellular communication mast affects the speed distribution of wind flow around it, we first consider the interaction of wind flow with a meteorological mast with the side width of $0.74 \mathrm{~m}$ [11]. Figure 1 shows a contour map of wind flow speed distribution around a lattice meteorological mast for wind speed $U=10.0 \mathrm{~m} / \mathrm{s}$ and the angle of wind direction $\alpha=0^{\circ}$ relative to the position of a boom with sensor $S$ on the triangular lattice mast.

The position of sensor $S$ is fixed on the mast by a boom at a distance of $3.2 \mathrm{~m}$ relative to the triangular mast centre, to which one-metre-step concentric octagons are attached.

In turn, Fig. 2 demonstrates the speed distribution of a wind flow around a lattice cellular communication mast with side width $0.74 \mathrm{~m}$ for wind speeds $U=5.0$ and $10.0 \mathrm{~m} / \mathrm{s}$ and the angles of wind direction $\alpha=0^{\circ}$ and $180^{\circ}$.

The colours on the contour map are associated with wind speed deviations in the modelled wind flow, wherein light yellow area corresponds to $100.0 \pm 1.0 \%$ of the undisturbed wind flow speed values, green area to $101.0-101.5 \%$, red area to more than $101.5 \%$, violet area to 98.5-99.0\%, and brown area to less than $98.5 \%$. The contour maps show wind flow speed that would satisfy the IEC standard requirements in light yellow, green and violet areas, while in the 


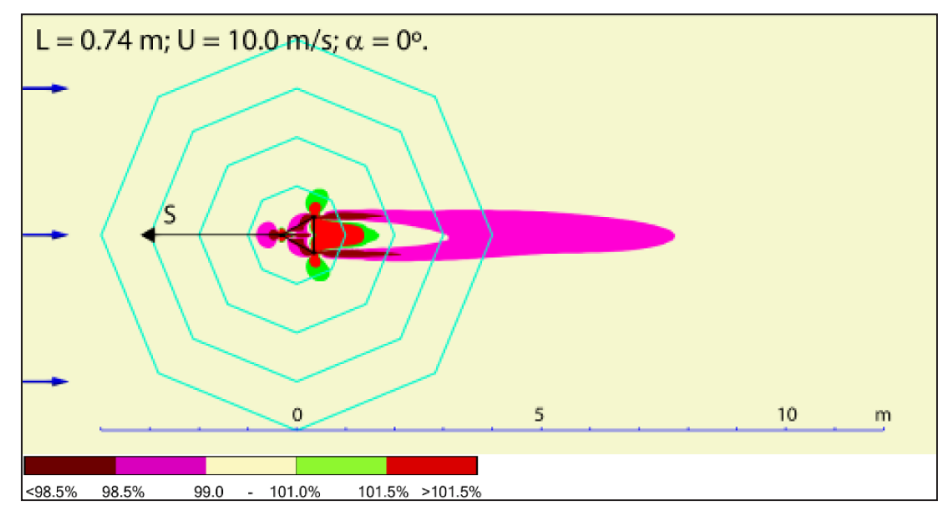

Fig. 1. CFD model of the wind flow interaction with a triangular lattice meteorological mast, side width $L=0.74 \mathrm{~m}$, for wind speed $U=10.0 \mathrm{~m} / \mathrm{s}$ and angle $a=0^{\circ}$ relative to the position of a boom with sensor $S$

red and brown regions deviations would exceed the allowed error margin.

The use of CFD models shows that the presence of cable lines inside a triangular lattice cellular communication mast slows down wind flow speed by more than $1.5 \%$ and causes the appearance of a narrow tail with the length of 7.0-9.0 $\mathrm{m}$ and angular dimensions of less than $10^{\circ}$. Within the boundaries of the remaining $350^{\circ}$ sector, the length of the region with wind speed distortions beyond $1.5 \%$ does not exceed $1.5-2.0 \mathrm{~m}$ from the mast centre.

Performed calculations make it possible to refine the results of prior studies indicating that the requirements of the IEC standard regarding the length of the boom are overestimated.

At the same time, the simulation results allow us to conclude that the standard does not guarantee the measurement accuracy of wind speed of $1.0 \%$ in the shadow area of the mast $\left(\alpha=180^{\circ}\right)$.

As can be seen from the contour maps in Fig. 2, the sizes of areas where wind speed measurement error would exceed $1.0 \%$ varies with increasing speed $U$ of modelled wind flow. In order to analyse this phenomenon, CFD modelling was performed for a wind flow field around a triangular lattice cellular communication mast with side widths $L=1.0 \mathrm{~m}$ and $1.2 \mathrm{~m}$, for wind

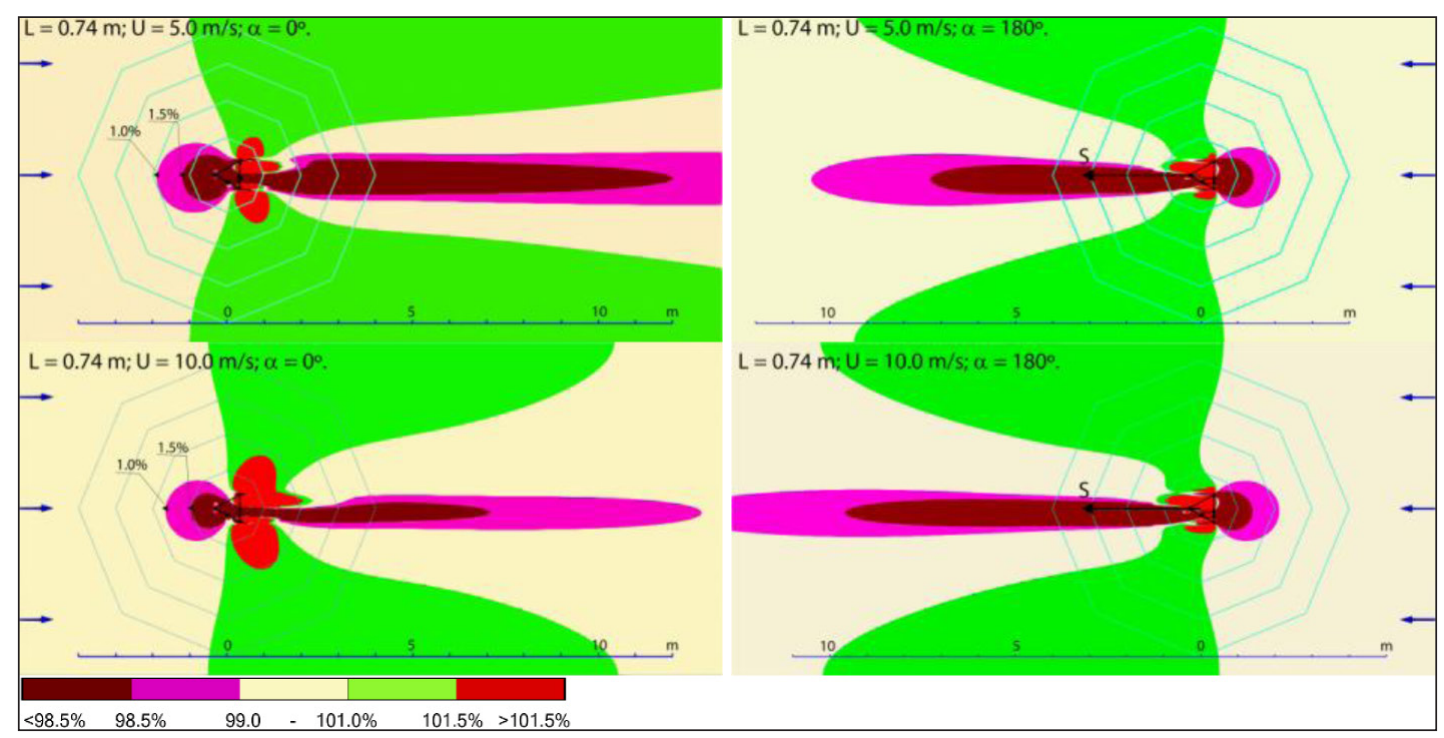

Fig. 2. CFD modelling results of the wind flow field around a triangular lattice cellular communication mast, side width $L=$ $0.74 \mathrm{~m}$, for wind speeds $U=5.0$ and $10.0 \mathrm{~m} / \mathrm{s}$ and angles $a=0$ and $180^{\circ}$ relative to the position of a boom with sensor $S$ 
speeds $U=5.0$ and $10.0 \mathrm{~m} / \mathrm{s}$ assuming that angle $\alpha=0^{\circ}$. The results of these calculations for wind speeds $U=5.0$ and $10.0 \mathrm{~m} / \mathrm{s}$ are presented in Fig. 3a, b. On the colour contour maps, distances from the mast centre to the boundaries of the fields corresponding to the 1.0 and $1.5 \%$ wind speed deviations are marked by solid black triangles.

Overall, an important conclusion can be made that the requirements of the IEC standard on wind measurements can be satisfied only if two sensors arranged in anti-phase are used simultaneously. Moreover, at the data processing stage it is necessary to consider only those measurements that do not come from a sensor located in the shadow of the mast. Such method of wind speed measurements would allow considerably lowering the requirement with respect to the minimum boom length. The relaxation of the requirements would result in much easier sensor installation process of sensors on measurement masts.

It is noteworthy that the use of paired sensors for wind measurements creates an opportunity to make use of the existing network of triangular lattice cellular communication masts. That considerably reduces the costs of data collection necessary for performing the assessment of wind energy resource potential.

\section{THE INSTALLATION OF MEASURING SENSORS ON CELLULAR COMMUNICATION MASTS}

The preparation of the experiment involved signing a lease agreement with a local mobile operator for the use of three masts located on the shore of the Baltic Sea in the area of Ventspils, Pavilosta and Ainazi, as shown in Fig. 4. For the experimental studies, triangular lattice masts of guyed type were chosen, which have a height of about $100 \mathrm{~m}$ with side dimensions of 1.2 and $1.4 \mathrm{~m}$, and

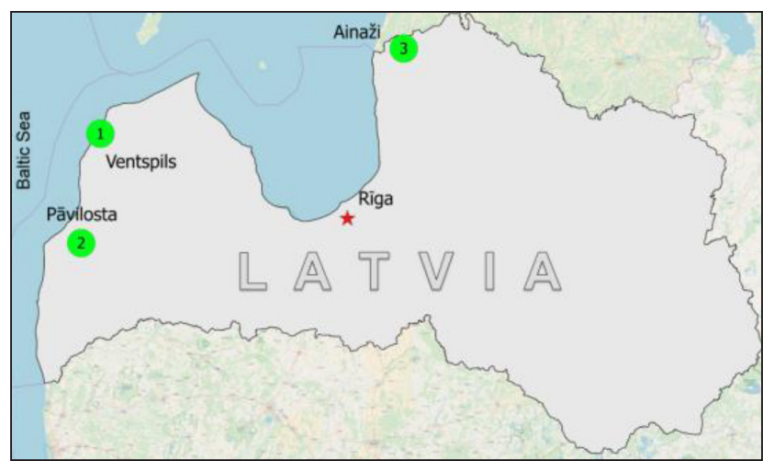

Fig. 4. The location map of three $100 \mathrm{~m}$ high lattice cellular communication masts, used in the experiment, on the shores of the Baltic Sea in Ventspils, Pavilosta and Ainazi regions

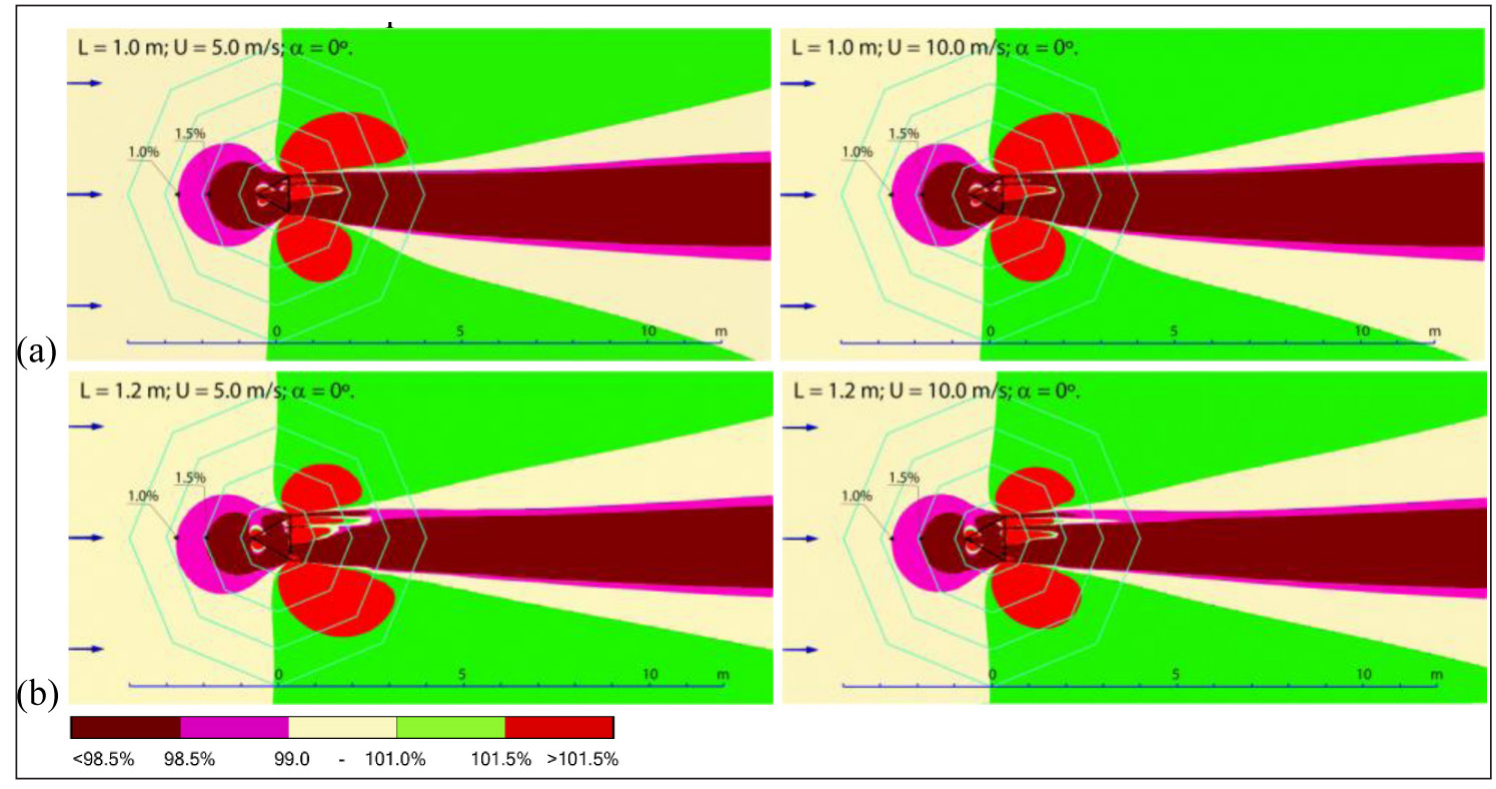

Fig. 3. CFD modelling results of the wind flow field around a triangular lattice cellular communication mast: (a) side width $L=1.0 \mathrm{~m}$ and (b) side width $L=1.2 \mathrm{~m}$, for wind speeds $U=5.0$ and $10.0 \mathrm{~m} / \mathrm{s}$ and the angle $a=0^{\circ}$ relative to the position of a boom with sensor $S$ 
located in the vicinity of existing ten-meter height masts of meteorological stations. According to the results, which are given in another study [12], these regions are promising for WPPs. Wind measurements at these sites were started on the following dates: Ventspils -21.12.2017, Pavilosta - 11.01.2018, Ainazi - 21.01.2018. and scheduled to last at least till the end of 2018. This paper discusses the measurement results obtained until 06.03.2018.

One of the masts that was used in the experiment and located in Ventspils region is shown in Fig. 5. The sensors were installed at four levels in places free of antennas and equipment on $2.8 \mathrm{~m}$ long booms at an angle of $90^{\circ}$ with respect to the sides of the mast. In this case, two cup anemometers of WindSensor P2546A-OPR type were installed at 10,64 and $84 \mathrm{~m}$ levels, while at the height of $40 \mathrm{~m}$ three such sensors were installed.

Wind direction sensors were installed at a height of 40 and $84 \mathrm{~m}$, while thermometers were placed at a height of 10 and $84 \mathrm{~m}$. The location of two anemometers and a sensor of wind direction at $84 \mathrm{~m}$ is shown in Fig. 6. The position of three anemometers and a sensor of the wind direction at the level of $40 \mathrm{~m}$ is shown in Fig. 7.

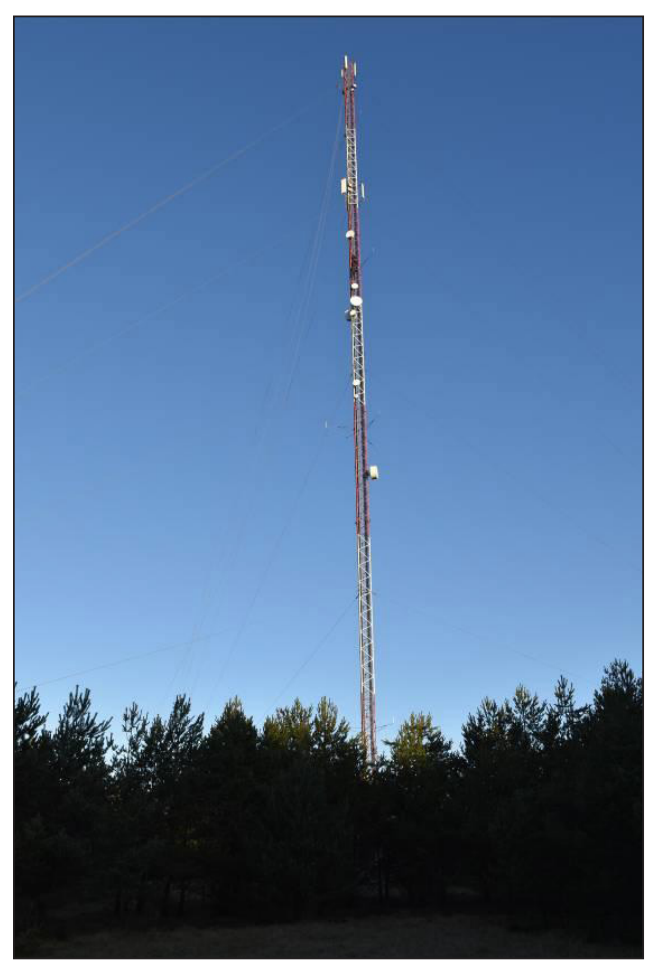

Fig. 5. Guyed type lattice triangular mast, which has a height of about $100 \mathrm{~m}$ with the side width of $1.2 \mathrm{~m}$

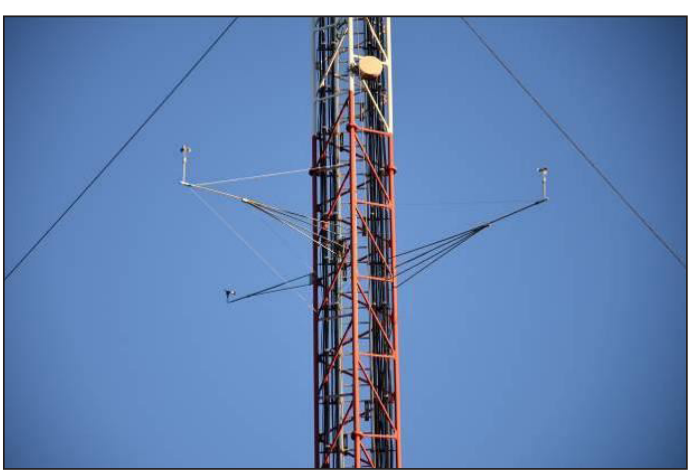

Fig. 6. The position of two anemometers and a sensor of wind direction at a height of $84 \mathrm{~m}$

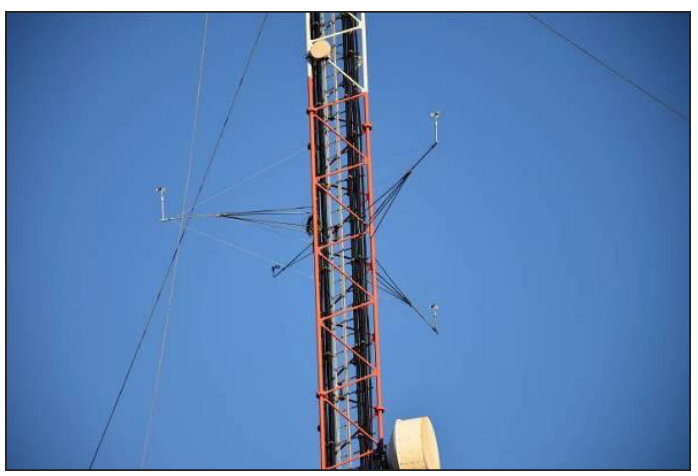

Fig. 7. The position of three anemometers and a sensor of wind direction at a height of $40 \mathrm{~m}$

The placement of an anemometer of WindSensor P2546A-OPR type at the end of the boom and the installation of the LOGGER NRG Symphonie PLUS3 in the lower part of the mast where the hygrometer and a photovoltaic panel are located can be seen in Figs. 8 and 9. The transfer of data from the registering unit is performed using a GSM module build in the Symphonie iPACK unit.

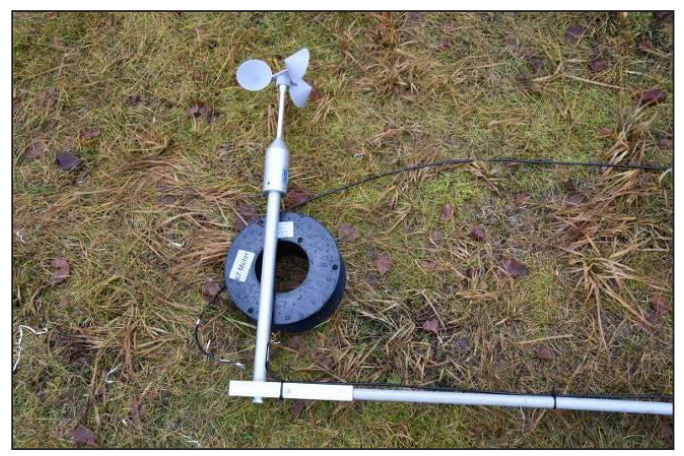

Fig. 8. Wind measurement cup anemometer of WindSensor P2546A-OPR type placed at the end of the boom 


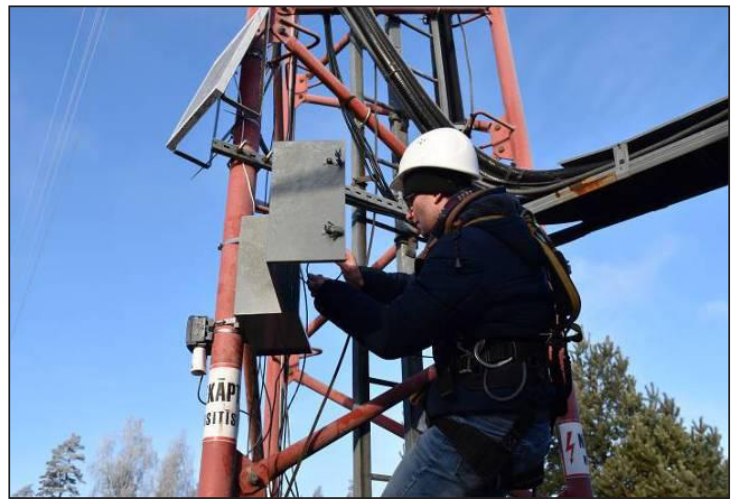

Fig. 9. The installation of the LOGGER NRG Symphonie PLUS3, hygrometer and a photovoltaic panel on the mast

The arrangement of anemometers $S_{A}, S_{B}, S_{C}$ and a wind direction sensor $S_{D i r}$ on a mast located in Ventspils at a height of 40 meters is shown in Fig. 10. Given that an anemometer is installed on a $2.8 \mathrm{~m}$ long boom, its distance from the mast centre $\mathrm{O}$ with a side width $L=1.2 \mathrm{~m}$ is $3.2 \mathrm{~m}$. The position of wind direction sensors $S_{\text {Dir }}$ with respect to the northward direction $\mathrm{N}$ is adjusted by setting the offset angle $\beta$ in the LOGGER device settings. For masts in Ventspils, Pavilosta and

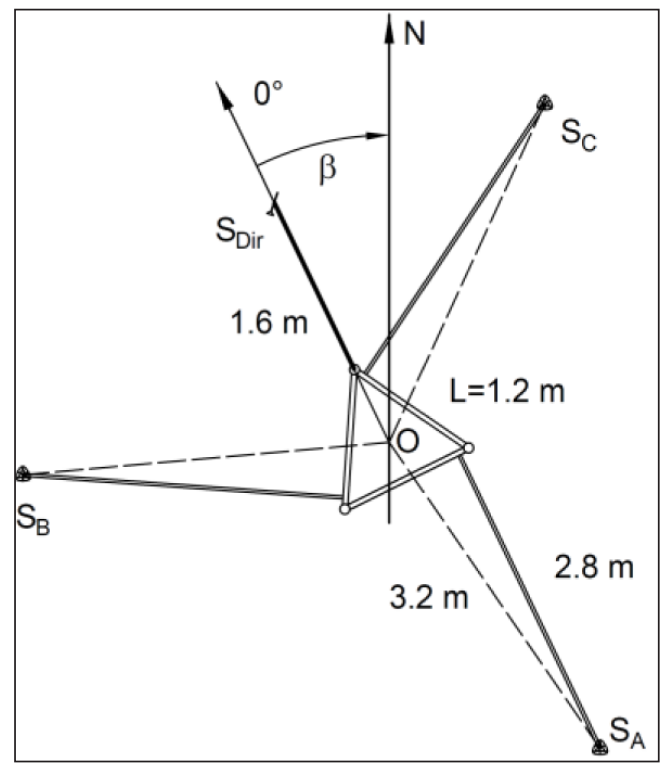

Fig. 10. The vector diagram of the arrangement of a wind direction sensor $S_{\text {Dir }}$ on a $1.6 \mathrm{~m}$ boom with an angle of offset $\beta$ with respect to the northward vector $N$ and anemometers $S_{A^{\prime}} S_{B^{\prime}} S_{C}$ on $2.8 \mathrm{~m}$ long booms that are located at a $3.2 \mathrm{~m}$ distance from the centre 0 of the triangular mast with a side length $L=1.2 \mathrm{~m}$
Ainazi, the values of this angle are, respectively, equal to: $-26^{\circ},-54^{\circ}$ and $51^{\circ}$.

The setup works of measuring systems were carried out in the period from 21.12.2017 to 19.01.2018. In this case, despite a short period of light time, installation work took less than two days per mast. Thus, the use of stationary cellular communication masts makes it possible to significantly reduce the time and material resources required to study the potential of wind energy at a height of up to 100 meters above the ground level.

\section{THE ANALYSIS OF WIND SPEED MEASUREMENT RESULTS}

The transfer of data from the measuring complexes is performed once a day via GSM mobile communication channels. Overall, the process of obtaining daily data for all 10-min measurements of wind parameters does not pose a problem. The received information is stored in a database, which allows to quickly monitor the operation of the complexes at a distance and analyse the information received.

At the same time, it should be noted that the database contains wind speed values recorded from anemometers also at a time when they were in the shadow of the mast. Consequently, these values will distort the resulting value of the wind speed, calculated as an average value over the entire measurement period.

From the above pictures of modelling the airflow around a mast, it can be seen that when measuring wind speed using two or three sensors offset by $120^{\circ}$ from each other, at each moment only one sensor can be in the shadow of the mast. Therefore, if the calculations of average wind speed from the database exclude measurements made by the sensor located in the shadow of the mast, then it should be possible to increase the reliability of the result of calculations.

According to the analysis of the results of 10-min measurements for two sensors located at the same height, it can be assumed that the ratio of their values should characterize the deviation of the airflow velocity in the corresponding sector around the mast. Therefore, the results of wind speed measurements of all sensors were grouped by time of measurement and in the direction from $0^{\circ}$ to $360^{\circ}$ with the steps of $1^{\circ}$. 
The results of simultaneous wind speed measurements by two anemometers installed at the same height with $120^{\circ}$ displacement makes it possible to estimate the degree of wind flow distortion caused by the mast structure. For quantitative evaluation of wind flow distortion degree, the following equation can be used:

$$
\mathrm{C}_{\mathrm{w}}=\mathrm{V}_{\mathrm{A}} / \mathrm{V}_{\mathrm{B}}
$$

where $V_{A}$ and $V_{B}$ are 10-min wind speed measurements for sensors $S_{A}$ and $S_{B}$, at the same height.

The analysis of wind flow distortion derived from anemometers $S_{A}, S_{B}$ and $S_{C}$ mounted on masts at a height of $40 \mathrm{~m}$ are presented in Fig. 11 for Pavilosta and Fig. 12 for Ventspils.

The ratios calculated using Eq. 1 for sensors $S_{A}$ and $S_{B}$ (red diamonds) and sensors $S_{A}$ and $S_{C}$ (green circles) in relationship to the angle of wind direction, averaged in steps of one degree are shown in Fig. 11. The figure shows distinctive peaks corresponding to the wind direction angles $105^{\circ}$ and $225^{\circ}$ with respect to angle $0^{\circ}$ of the sensor $S_{D i r}$. It is important to note that the flow velocity in these directions, which corresponds to the mast shadow, measured at all heights from 10 to $84 \mathrm{~m}$ shows speed reduction up to $50 \%$. The modelling results given in papers $[7,13]$ for meteorological masts indicate that the speed drop can reach $30-35 \%$. The difference between the estimates can be explained by the presence of cable lines inside the cellular communication mast.

For other directions, wind speed distortions recorded by the sensors do not exceed $\pm 5 \%$. The simulation results suggest that the maximum value in these areas arises when one sensor is in a zone where the flow velocity increases and the second one is in the zone where the flow is slowing down. Thus, the actual deviation of the wind speed does not exceed $2.5 \%$. In turn, the simulation results predict in these areas a change in the flow rate of about $2 \%$.

As a result of the analysis of obtained wind speed measurement values using a vector diagram depicted in Fig. 10 and curves $C_{w}$, it can be seen that there are three directions around the mast that create a shadow for the sensors in the process of wind speed measurements. An illustration of the areas and angles of shading for Ventspils site are shown in the vector diagram in Fig. 12, where the direction angles for the wind flows $W_{A}, W_{B}$, $W_{C}$ relative to the northward direction $N$ are, respectively, $-40^{\circ}, 80^{\circ}$ and $-150^{\circ}$.

In Fig. 12, the boundaries of the shadow region are depicted approximately, while the shape of the curves on Fig. 11 and models in Fig. 3 suggests that the shadow region has a conical shape. At the same time, it can be seen that the shadow

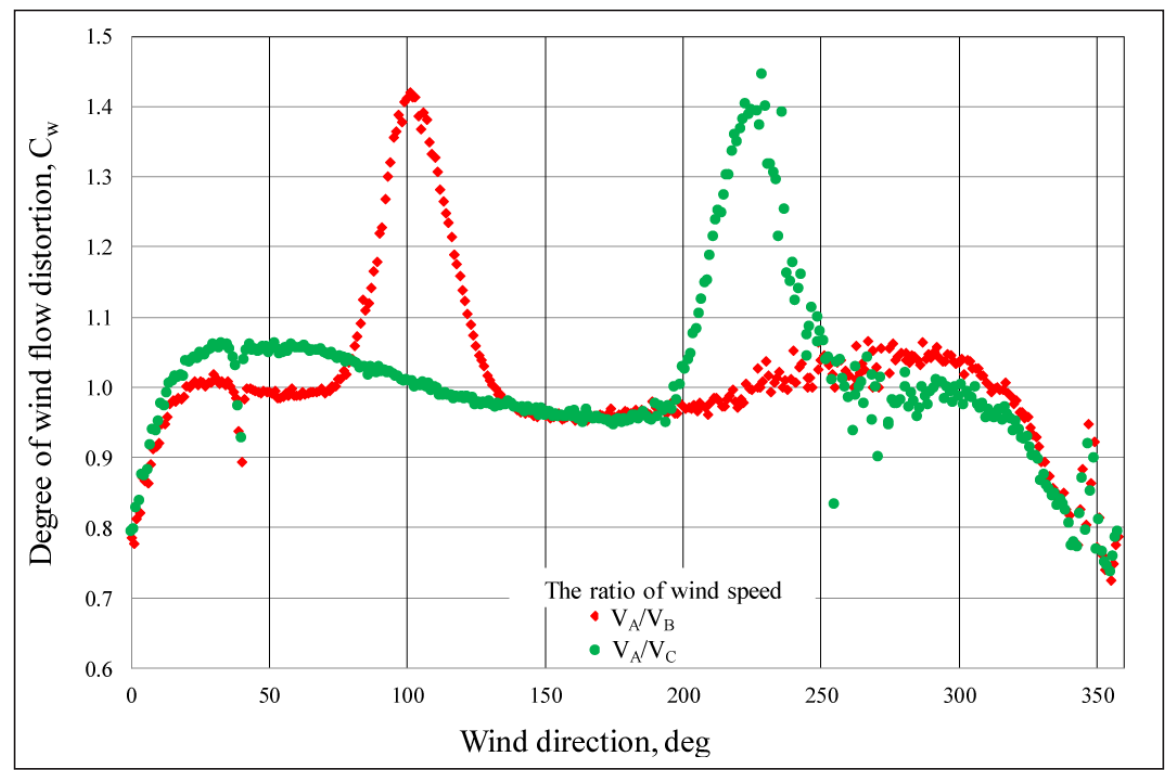

Fig. 11. The degree of wind flow distortion $C_{W}$ of measured wind speeds from sensors $S_{A}$ and $S_{B}$ (red diamonds) and $S_{A}$ and $S_{C}$ (green circles) located in Pavilosta site at a height of $40 \mathrm{~m}$, in relationship to the angle of wind direction 


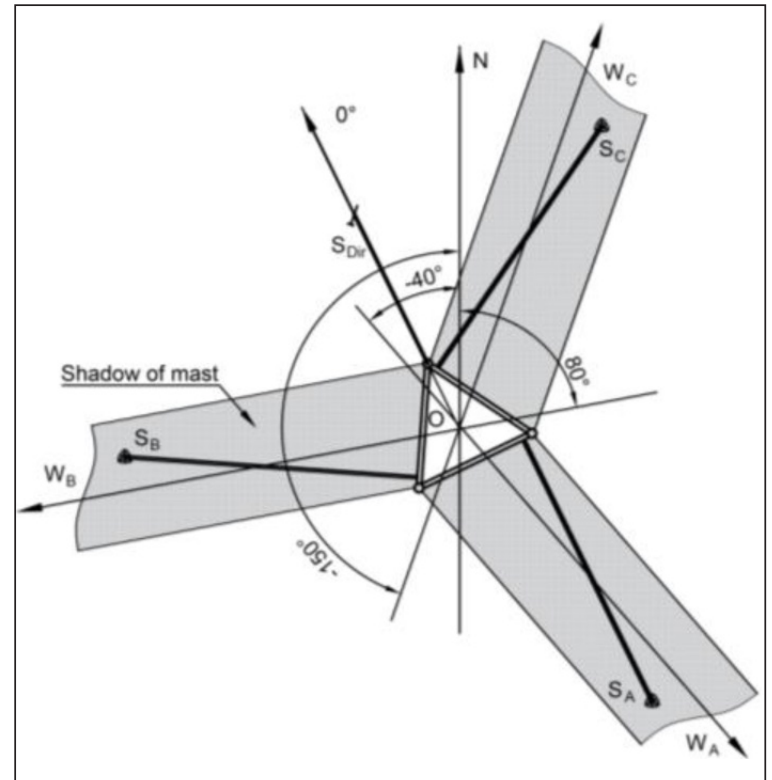

Fig. 12. The vector diagram of the wind flows $W_{A^{\prime}} W_{B^{\prime}}, W_{C^{\prime}}$ which create a shadow from the mast for sensors $S_{A^{\prime}} S_{B^{\prime}} S_{C}$ and the corresponding angles of directions $-40^{\circ}, 80^{\circ}$ and $-150^{\circ}$ relative to the direction vector north $\mathrm{N}$ for Ventspils site area has a displacement and is not perpendicular to the side of the mast. The displacement can be attributed to the presence of communication lines and ladders inside the mast and non-symmetric wind sensor position with respect to the mast side.

Based on the simulation results and experimental studies presented above, it can be concluded that for each sensor on the mast there is a sector within which the results of wind speed measurements will not meet the requirements of the standard. However, the size of this sector does not exceed $70^{\circ}$. It follows that in order to measure wind speed in accordance with the requirements of the standard, two sensors offset by an angle of at least $120^{\circ}$ must be used and the results of measurements should be related to the direction of the wind flow.

In this case, the measured values of wind speed, which are obtained in the area shaded from the wind, must be excluded from calculations. Therefore, in order to estimate wind speed,

Table 1. Values of average wind speeds $\left(V_{\text {avg }}\right)$ before and after corrections $\left(V_{\text {avg_corr }}\right)$ and their difference $\left(1-\frac{V_{\text {avg }}}{V_{\text {avgcorr }}}\right)$ in percents for sensors SA, SB, SC, installed on cellular communication masts in Ventspils, Pavilosta and Ainazi at the heights of 10, 40, 64 and $84 \mathrm{~m}$

\begin{tabular}{|c|c|c|c|c|c|c|c|c|c|c|}
\hline \multirow{4}{*}{ 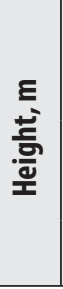 } & \multirow{4}{*}{ Sensors } & \multicolumn{9}{|c|}{ Location sites } \\
\hline & & \multicolumn{3}{|c|}{ Ventspils } & \multicolumn{3}{|c|}{ Pavilosta } & \multicolumn{3}{|c|}{ Ainazi } \\
\hline & & \multicolumn{2}{|c|}{$\begin{array}{l}\text { Average wind } \\
\text { speed, } \mathrm{m} / \mathrm{s}\end{array}$} & \multirow{2}{*}{ Diff., \% } & \multicolumn{2}{|c|}{$\begin{array}{l}\text { Average wind speed, } \\
\mathrm{m} / \mathrm{s}\end{array}$} & \multirow{2}{*}{ Diff., \% } & \multicolumn{2}{|c|}{$\begin{array}{l}\text { Average wind speed, } \\
\mathrm{m} / \mathrm{s}\end{array}$} & \multirow{2}{*}{ Diff., \% } \\
\hline & & $V_{\text {avg }}$ & $V_{\text {avg_corr }}$ & & $V_{\text {avg }}$ & $V_{\text {avg_corr }}$ & & $V_{\text {avg }}$ & $V_{\text {avg_corr }}$ & \\
\hline \multirow{3}{*}{10} & $S_{A}$ & 2.27 & 2.29 & $0.9 \%$ & 1.87 & 1.90 & $1.3 \%$ & 2.55 & 2.55 & $0.1 \%$ \\
\hline & $S_{B}$ & 2.22 & 2.31 & $3.6 \%$ & 1.81 & 1.91 & $5.3 \%$ & 2.45 & 2.56 & $4.5 \%$ \\
\hline & $\frac{S_{A}+S_{B}}{2}$ & 2.25 & 2.30 & $2.3 \%$ & 1.84 & 1.91 & $3.3 \%$ & 2.50 & 2.56 & $2.3 \%$ \\
\hline \multirow{4}{*}{40} & $S_{A}$ & 4.21 & 4.27 & $1.4 \%$ & 3.60 & 3.67 & $1.9 \%$ & 3.72 & 3.74 & $0.6 \%$ \\
\hline & $S_{B}$ & 4.15 & 4.26 & $2.7 \%$ & 3.53 & 3.69 & $4.3 \%$ & 3.55 & 3.78 & $5.9 \%$ \\
\hline & $S_{C}$ & 4.11 & 4.25 & $3.2 \%$ & 3.62 & 3.65 & $1.0 \%$ & 3.57 & 3.76 & $5.0 \%$ \\
\hline & $\frac{S_{A}+S_{B}+S_{C}}{3}$ & 4.16 & 4.26 & $2.5 \%$ & 3.58 & 3.67 & $2.4 \%$ & 3.62 & 3.76 & $3.9 \%$ \\
\hline \multirow{3}{*}{64} & $S_{A}$ & 5.27 & 5.35 & $1.5 \%$ & 4.42 & 4.52 & $2.2 \%$ & 4.19 & 4.21 & $0.5 \%$ \\
\hline & $S_{B}$ & 5.28 & 5.40 & $2.2 \%$ & 4.37 & 4.55 & $3.9 \%$ & 4.02 & 4.25 & $5.4 \%$ \\
\hline & $\frac{S_{A}+S_{B}}{2}$ & 5.27 & 5.38 & $1.9 \%$ & 4.39 & 4.53 & $3.0 \%$ & 4.11 & 4.23 & $3.0 \%$ \\
\hline \multirow{3}{*}{84} & $S_{A}$ & 6.05 & 6.16 & $1.7 \%$ & 4.86 & 4.98 & $2.2 \%$ & 4.70 & 4.72 & $0.4 \%$ \\
\hline & $S_{B}$ & 6.11 & 6.25 & $2.2 \%$ & 4.82 & 5.00 & $3.6 \%$ & 4.49 & 4.74 & $5.4 \%$ \\
\hline & $\frac{S_{A}+S_{B}}{2}$ & 6.08 & 6.20 & $1.9 \%$ & 4.84 & 4.99 & $2.9 \%$ & 4.59 & 4.73 & $2.9 \%$ \\
\hline
\end{tabular}


observations from one sensor are used, which at the time is located outside of the shadow area.

The average wind speed values $V_{\text {avg }}$ obtained from measurements and corrected average wind speeds $V_{\text {avg_corr }}$ for anemometers $S_{A}, S_{B}, S_{C}$ at heights of 10, 40, 64 and $84 \mathrm{~m}$ for the entire measurement periods on each site are given in Table 1. Along with this, the table shows mean wind speed values for each height and difference in percent between raw and corrected values.

Based on the measurement results it is possible to conclude that wind speed values recorded from anemometers for one height differ among themselves within several percent. In this case, the real value of the wind speed differs from the measured values by same level.

The comparison of the results of measurements of wind speed shows that, as a result of the correction, the average speed at all heights increased by $\sim 1.9-3.9 \%$. Since distorted values were excluded from the calculations, this means that the reliability of the measurement results has increased by a similar amount.

\section{CONCLUSIONS}

The recommendation of the IEC 61400-12-1 standard for the choice of boom length does not guarantee that measurements are taken with the required accuracy of $1 \%$ between $0^{\circ}$ and $360^{\circ}$ degrees around the mast.

The study presents the results of calculating the average value of wind speed $V_{\text {avg }} \mathrm{m} / \mathrm{s}$ for three coastal sites in Latvia at the heights of $10,40,64$ and $84 \mathrm{~m}$ for the entire measurement period with and without filtering out distorted measurement data on the basis of wind flow direction.

In order to increase the reliability of the results of wind speed measurements, it is sufficient to use two anemometers offset by at least $120^{\circ}$ from each other in combination with a wind direction sensor used for determining the direction of the shadow induced by the mast. Further increase in the number of sensors installed on a mast for the purpose of performing wind speed measurements does not improve the reliability of the flow velocity measurement.

The reliability of average wind speed estimation increases after the exclusion of distorted measurements from calculations. As a result of such correction, the speed values at all heights increased by $\sim 1.9-3.9 \%$ on average.

The use of stationary cellular communication masts for wind speed measurements provides a valid option for significantly reducing the time and material resources required to study the potential of wind energy at the height of up to 100 meters above ground level.

\section{ACKNOWLEDGEMENTS}

The work is carried out within the project $\mathrm{New} \mathrm{Eu}-$ ropean Wind Atlas (NEWA), ENER/FP7/618122/ NEWA ERA-NET PLUS, supported by the EUROPEAN COMMISSION under the 7th Framework Programme for Research, Technological Development and Demonstration.

Received 1 February 2018 Accepted 15 March 2018

\section{References}

1. Bezrukovs V., Bezrukovs Vl. Wind speed and energy at different heights on the Latvian coast of the Baltic Sea. Journal of Energy and Power Sources. 2006. Vol. 1. No. 2. P. 105-112.

2. Wind Turbines - Part 12-1: Power Performance Measurements of Electricity Producing Wind Turbines. IEC 61400-12-1:2017, Geneva, Switzerland.

3. Farrugia R. N., Sant T. Modelling wind speeds for cup anemometers mounted on opposite sides of a lattice tower: A case study. Journal of Wind Engineering and Industrial Aerodynamics. 2013. Vol. 115. P. 173-183.

4. Gioffrè M., Gusella V., Materazzi A. L., Venanzi I. Removable guyed mast for mobile phone networks: wind load modelling and structural response. Journal of Wind Engineering and Industrial Aerodynamics. 2004. Vol. 92. P. 463-475.

5. Perrin D., McMahon N., Crane M., Ruskin H. J., Crane L., Hurley B. The effect of meteorological tower on its top-mounted anemometer. Applied Energy. 2007. Vol. 84 Issue 4. P. 413-424.

6. Hansen M., Pedersen B. Influence of the Meteorology Mast on a Cup Anemometer, Journal of Solar Energy Engineering. 1999. Vol. 121. P. 128-131. 
7. Stickland M., Scanlon T., Fabre S., Oldroyd A., Kindler D. Measurement and simulation of flow field around a triangular lattice meteorological mast, Journal of Energy and Power Engineering. 2013. Vol. 7. Issue 10. P. 1934-1939.

8. Fabre S. et al. Computational and experimental study on the effect of flow field distortion on the accuracy of the measurements made by anemometers on the fino3 meteorological mast. EWEA Offshore 2011, Amsterdam. https://pure. strath.ac.uk/portal/files/12844048/Stickland_ MT_et_al_Pure_Computational_and_experimental_study_on_the_effect_of_flow_field_distortion_on_the_accuracy_of_measurements..._ Fino3_Meteorological_mast_Nov_2011.pdf.

9. Fabre S. CFD Modelling of Flow Distortion Using OpenFOAM. Mphil Thesis. UK: University of Strathclyde, 2011.

10. Fabre S., Stickland M., Scanlon T., Oldroyd A., Kindler D., Quqil F. Measurement and simulation of flow field around the FINO 3 triangular lattice meteorological mast. Journal of Wind Engineering and Industrial Aerodynamics. 2014. Vol. 130 P. 99-107.

11. Bezrukovs V., Bezrukovs Vl., Upnere S., Bezrukovs D., Sauhats A. The assessment of wind speed distortions in a simulated flow around a lattice cellular communication mast. EECS 2017 European Conference on Electrical Engineering and Computer Science, Bern, Switzerland, November 17-19, 2017.

12. Aniskevich S., Bezrukovs V., Zandovskis U., Bezrukovs D. Modelling the spatial distribution of wind energy resources in Latvia. Latvian Journal of Physics and Technical Sciences. 2017. N 6. Vol. 54. P. 10-20.

13. Orlando S., Bale A., Johnson D. A. Experimental study of the effect of tower shadow on anemometer readings. Journal of Wind Engineering and Industrial Aerodynamics. 2011. Vol. 99. Issue 1. P. 1-6.
Valerijs Bezrukovs, Vladislavs Bezrukovs, Sabine Upnere, Linda Gulbe

\section{RYŠIŲ BOKŠTŲ NAUDOJIMAS VĖJO ŠLYTIES TYRIMAMS}

\section{Santrauka}

Prieš pradedant bet kurị vejo jẻgainių parko statybos projektą, būtina atidžiai ịvertinti galimą vejjo potencialą pasirinktoje teritorijoje. Tokių tyrimų išlaidos yra didelès, jos siekia kelias dešimtis tūkstančių eurų, net jei tai santykinai mažas $70 \mathrm{~m}$ aukščio stiebas. Siekiant sumažinti vejo greičio matavimų išlaidas siūloma naudoti Europoje plačiai išdèstytus esamus mobiliųjų ryšių bokštus. Straipsnyje pateikiama metodologija ir vejjo greičio bei vejjo šlyties matavimų, atliktų naudojant esamus iki 100 m aukščio mobiliųjų ryšių bokštus, rezultatai. Siekiant ištirti bokšto konstrukcijos įtaką vejjo greičio matavimų kokybei, buvo sukurtas oro srauto aplink mobiliojo ryšio bokštą skaitinis modelis. Straipsnyje pateikiamos CFD modeliavimo vizualizacijos, vaizduojančios oro srauto trikdžių dydị aplink stiebą. Tyrimas remiasi eksperimentiniais matavimais, atliktais $2018 \mathrm{~m}$. trijose Latvijos pakrantès vietose. Kiekvienoje matavimų aikštelèje vejjo greitis ir kryptis buvo matuojami keliuose aukščiuose, fiksuota oro temperatūra, drègmè ir oro slègis. Remiantis eksperimentinių duomenų bei skaitinių rezultatų analize parodyta galimybė naudoti mobiliojo ryšio stiebus tiksliems vejjo greičio matavimams. Atliktas tyrimas rodo, kad siūloma vejjo greičio matavimo metodika gali pateikti tikslius duomenis ir sumažinti bendrąsias vejjo energetikos projektų išlaidas.

Raktažodžiai: vejjo greičio matavimas, CFD modeliavimas, ažūrinis stiebas, vèjo šlytis 